\title{
BCL FORUM《中國語言學集刊》論壇
}

Beginning with the current Issue, the Bulletin of Chinese Linguistics (henceforth BCL) initiates a Forum for friendly discussion and debate of controversial but meaningful topics in the linguistic areas that BCL is involved with, namely the areas that the late Professor Li Fang-Kuei devoted his research to: historical and comparative study, inclusive of typology and dialectology, of all varieties of the Sinitic language, of Tibetan and other Tibeto-Burman languages, and of Tai languages.

《中國語言學集刊》（以下簡稱BCL）自本期開設論壇, 以供同道在友好的氣氛中盡情表達意見, 討論各項有爭議的重大學術問題。討論的對象, 主要是李方桂先生致力的漢、藏、台語等相關語 言, 取徑則為歷史及比較研究方法, 亦包括類型學與方言學。

Five volunteer editors for this Forum, named Forum Editors, have been selected from among the broadminded Li Fang-Kuei Society Young Scholars who have a wide range of academic interests and enthusiasm for service, and who can instill new blood and excitement into BCL.

五位論壇編輯, 選自心胸開闊、興趣廣泛、有服務熱誠的李方桂學會青年學者, 為BCL注入新血及 活力。

The breadth of interests and expertise of these five Forum Editors are, alphabetically: 其興趣及專業如下：

Deng, Lin 鄧琳—early Chinese texts and inscriptions (especially the oracle-bone inscriptions); historical phonology, morphology, and syntax; dialectology.

早期漢語出土文獻（尤其甲骨文）；歷史音韻學；上古漢語形態學與句法學；方言學。

Hill, Nathan-Classical Tibetan, Tibeto-Burman languages; Archaic Chinese phonology; reconstruction; verb morphology; Sino-Tibetan comparison.

古典藏語 ; 藏緬語 ; 漢語上古音 ; 古音擬測 ; 動詞形態 ; 漢藏比較。

Jacques, Guillaume-historical linguistics; Rgyalrongic languages; Kiranti languages, Archaic Chinese, Sino-Tibetan; Tangut; Hmong-mien; phonology, morphosyntax; language contact; language phylogeny. 歷史語言學； 嘉絨語支；基蘭提語支；漢語上古音；漢藏語系；西夏文；苗瑤語族；音系學； 形態句法; 語言接觸 ; 語言譜系。

List, Mattis-Computer-based and computer-assisted approaches to historical linguistics and Chinese historical phonology; computer-based and computer-assisted language comparison of Southeast Asian languages.

基於計算機和計算機輔助的歷史語言學和漢語歷史音韻學方法；基於計算機和計算機輔助的東南亞 語言之語言比較。 
$\mathrm{Wu}$, Rui-wen 吳瑞文—historical linguistics; reconstruction of proto-dialects and the relation between proto-dialects and Chinese historical phonology; Chinese historical grammar and comparative dialectal grammar.

歷史語言學 ; 現代方言之祖語擬測及其與漢語音韻史的關係 ; 現代漢語方言語法史與書面漢語語法 史之比較研究。

The selection of topics for each Forum, solicitation of articles, and invitation of reviewers for each article are all undertaken by these Forum Editors.

議題由論壇編輯各自提出，各自徵稿，審稿人也由論壇編輯聯繫邀請。

To constitute a Forum for meaningful discussion and debate, each Forum consists of at least two papers. Depending on the number of papers selected, the Forum may constitute either part of a volume/issue of BCL, or stand as an independent volume/issue of BCL.

為促成建設性的討論, 甚至辯論, 論壇每期至少包含兩篇文章。根據入選文章篇幅、數量, 論壇或 為一卷/期之專欄, 或獨立為一卷/期。

All Forum articles are in the form of full-length, academically sound papers that have gone through the regular BCL review process.

論壇文章需首尾完整, 且符合學術論文的形式要求。審查則遵照 $\mathbf{B C L}$ 的一般原則與程序。

After the Forum is launched it is open to all interested scholars without restriction.

論壇推出後，歡迎學者撰文公開討論，無任何限制。

Zev Handel, Director cum Treasurer of the Li Fang-Kuei Society, serves as Consultant for this Forum. 論壇由李方桂學會董事兼司庫韓哲夫擔任顧問。

BCL Editors-in-Chief

《中國語言學集刊》主編 